\title{
CADAVER PRESERVATION FOR SURGICAL SKILL TRAINING: COMPARISON OF TWO EMBALMING FORMULATIONS
}

\section{PRESERVAÇÃO DE CADÁVERES PARA TREINAMENTO CIRÚRGICO: COMPARAÇÃO ENTRE DUAS FORMULAÇÕES DE EMBALSAMENTO}

\author{
Erika De Brito Marco Zanuto ${ }^{1 *}$ - ORCID http://orcid.org/0000-0002-7233-5550 \\ Maria Cláudia Campos Mello Inglez de Souza1 - ORCID http://orcid.org/0000-0002-6266-0931 \\ Antonio Augusto Coppi Marcel Ribeiro ${ }^{1}$ - ORCID http://orcid.org/0000-0002-8656-0409 \\ Julia Maria Matera ${ }^{1}$ - ORCID http://orcid.org/0000-0001-8349-1340 \\ 'Universidade de São Paulo, São Paulo, SP, Brazil \\ "Corresponding author - erika.zanuto@usp.br
}

\begin{abstract}
At the School of Veterinary Medicine and Animal Science, University of São Paulo, Brazil, preliminary surgical training involving live animals has been replaced by the use of embalmed canine cadavers. This study aimed to improve the embalming technique based on the modified Larssen solution by altering the original formulation. Twenty-four canine corpses obtained according to the norms and resolutions described by the animal research ethics committee were used in this study. The cadavers were randomly allocated to two groups, G1 and G2, and treated with modified Larsen solution containing $20 \%$ and $10 \%$ formalin, respectively. The Larssen solution used in G1 contained a higher volume of distilled water and higher formalin concentration than the one used in G2. Cadavers were used in hands-on surgical training labs for four weeks. The following evaluation criteria were considered: general appearance, muscle tissue color, tissue texture/consistency, joint flexibility, odor development, and skin integrity in the abdominal and other regions involved in surgical training. The cadavers in both groups showed good general appearance and retained satisfactory organoleptic properties for surgical training throughout the experimental period. There was no significant difference between the groups treated with $20 \%$ or $10 \%$ modified Larssen solution ( $\mathrm{p}>0.05$; chi-square test). The present findings were considered positive, because the dilution of the original formulation exhibited similar efficacy and required smaller amounts of chemicals, thus reducing the formulation cost.
\end{abstract}

Keywords: alternative methods; teaching; modified Larssen solution

\section{Resumo}

$\mathrm{Na}$ Escola de Medicina Veterinária e Zootecnia da Universidade de São Paulo, o treinamento cirúrgico inicial em animais vivos foi substituído pelo uso de cadáveres caninos quimicamente preservados. $\mathrm{O}$ objetivo deste estudo foi melhorar a técnica de embalsamamento baseada na solução Larssen modificada através de modificações em sua formulação original. Vinte e quatro cadáveres caninos obtidos conforme as normas e resoluções descritas pelo comitê de ética em pesquisa animal foram utilizados neste estudo. Os cadáveres foram divididos aleatoriamente em dois grupos (G1 ou G2) e tratados com solução modificada de Larssen contendo $20 \%$ e $10 \%$ de formalina, respectivamente. A solução de Larssen usada em G1 continha um maior volume de água destilada e maior concentração de formalina em comparação com o utilizado em G2. Os cadáveres foram utilizados no laboratório de treinamento cirúrgico prático durante quatro semanas. Foram considerados os seguintes critérios de avaliação: aparência geral, cor do tecido muscular, textura/consistência do tecido, flexibilidade das articulações, desenvolvimento de odor e integridade da pele na região abdominal e outras regiões envolvidas no treinamento cirúrgico. 
Os cadáveres em ambos os grupos apresentaram boa aparência geral e mantiveram as propriedades organolépticas satisfatórias para treinamento cirúrgico ao longo do período experimental. Os cadáveres tratados com $20 \%$ ou $10 \%$ de solução modificada de Larssen não diferiram significativamente ( $>>0,05$, teste de qui-quadrado). Os resultados deste estudo foram considerados positivos, visto que a diluição da formulação original produziu eficácia semelhante e, no entanto, exigiu quantidades menores de produtos químicos, diminuindo o custo da formulação.

Palavras-chave: métodos alternativos; ensino; solução de Larssen modificada

Received on November 11, 2017

Accepted on February 7, 2019

\section{Introduction}

Since the end of the last century, there have been constant efforts to find a more rational approach to animal use in experimental research, with greater focus on animal welfare and ethical principles ${ }^{(1)}$.

Universities are centers of excellence in higher education, and hence have strong institutional and opinionated leadership. Therefore, constant reassessment of pedagogical practices and implementation of innovative educational and research tools is crucial in academic settings ${ }^{(2)}$. Teaching and research practices involving animal use can be replaced by alternative methods that reduce or eliminate this need while promoting methodological improvement ${ }^{(1,3)}$.

At FMVZ-USP (School of Veterinary Medicine and Animal Science, University of São Paulo), surgical techniques are taught and related training is provided using canine cadavers preserved using the modified Larssen solution, with no negative impacts on learning ${ }^{(4)}$. Studies focusing on cadaver preservation are still scarce; however, these studies are needed not only for the refinement of existing methods, but also for the development of alternative techniques that satisfactorily preserve embalmed cadavers. This study set out to compare two embalming fluids derived from the modified Larssen solution.

\section{Methods}

The cadavers used in this study were ethically sourced from the FMVZ-USP Veterinary Hospital. These included dogs that had died or were euthanized due to incurable or terminal diseases and donated for research and/or teaching by their owners. The cadavers of animals that died of infectious or zoonotic diseases were excluded. Cadavers were stored in a cold chamber at $-8^{\circ} \mathrm{C}$ prior to chemical treatment.

Twenty-four cadavers of female and male dogs weighing up to $15 \mathrm{~kg}$ were prepared and analyzed in this study; the cadavers mean weight and standard deviation are shown in Table 1.

Table 1. Mean weight and standard deviation of the corpses used in the study

\section{G1 (treated with $20 \%$ \\ modified Larssen \\ solution)}

G2 (treated with $10 \%$

modified Larssen

solution)
Mean weight

Standard deviation
6.9

3.132
7.45

3.301 
The corpses were randomly allocated to the following two groups $(\mathrm{n}=12$, each): Group $1(\mathrm{G} 1)$, treated with 20\% modified Larssen solution; and Group 2 (G2), treated with 10\% modified Larssen solution. All cadavers were used in hands-on surgical training labs at FMVZ-USP.

The 20\% modified Larssen solution used in this study contained $2000 \mathrm{~mL}$ distilled water, $180 \mathrm{~g}$ sodium chloride (Dinâmica Analytical Reagents), 200 g sodium bicarbonate (Dinâmica Analytical Reagents), 200 g sodium sulphate (Dinâmica Analytical Reagents), 200 g chloral hydrate (Vetec Fine Chemicals Ltd.), $100 \mathrm{~mL}$ of $20 \%$ formalin (Miyako do Brasil Industry and Commerce Ltd.), and $400 \mathrm{~mL}$ liquid glycerin (Dinâmica Analytical Reagents). This formulation was further diluted with $5000 \mathrm{~mL}$ of distilled water. The $10 \%$ modified Larssen solution ${ }^{(4)}$ was prepared in a similar manner, but with $10 \%$ formalin and the subsequent addition of $3000 \mathrm{ml}$ of distilled water.

The addition of $5000 \mathrm{~mL}$ of distilled water in the $20 \%$ modified Larssen solution had an experimental criterion of obtaining a higher yield of the new solution as compared to the original formulation. However, in order to retain its conservative characteristic, it was decided to increase the formalin concentration (20\%) (Table 2).

Table 2. Dilution calculations used in the preparation of the two solutions

\begin{tabular}{ccc}
\hline Components & $\begin{array}{c}\mathbf{2 0 \%} \text { modified Larssen } \\
\text { solution }\end{array}$ & $\begin{array}{c}\mathbf{1 0 \%} \text { modified Larssen } \\
\text { solution }\end{array}$ \\
\hline Distilled water & $2000 \mathrm{~mL}$ & $2000 \mathrm{~mL}$ \\
Sodium chloride & $180 \mathrm{~g}$ & $180 \mathrm{~g}$ \\
Sodium bicarbonate & $200 \mathrm{~g}$ & $200 \mathrm{~g}$ \\
Sodium sulphate & $200 \mathrm{~g}$ & $200 \mathrm{~g}$ \\
Chloral hydrate & $200 \mathrm{~g}$ & $200 \mathrm{~g}$ \\
$20 \%$ formalin & $100 \mathrm{~mL}$ & -- \\
$10 \%$ formalin & -- & $100 \mathrm{~mL}$ \\
Liquid glycerin & $400 \mathrm{~mL}$ & $400 \mathrm{~mL}$ \\
Additional distilled water & $5000 \mathrm{~mL}$ & $3000 \mathrm{~mL}$ \\
for dilution & &
\end{tabular}

Fixative solutions were prepared at room temperature. Liquid and solid ingredients were alternately added to distilled water to achieve a completely homogenized solution. Solutions were stored in closed plastic containers, and labeled with the date of preparation and name of the person in charge.

The cadavers were thawed by immersion in room temperature water, washed in running water, and submitted to rectal enema to empty the colon. Thawed cadavers were inspected for signs of putrefaction or skin changes and then taken to the surgical technique training facility for further preparation. The cadavers were placed in dorsal recumbency, and a sharp incision was made on the lateral surface of the neck to locate the neurovascular bundle comprising the internal jugular vein, right vagosympathetic trunk, and right carotid artery. The carotid artery was then cannulated to inject $0.9 \%$ warm $\left(40{ }^{\circ} \mathrm{C}\right)$ saline followed by modified Larssen solution, at volumes corresponding to $10 \%$ of the body weight.

Finally, the cadavers were washed with neutral soap and shampoo for debris removal, stored in labeled plastic bags, and hung in a cold chamber at $-8{ }^{\circ} \mathrm{C}$ until further use.

Cadavers were used in hands-on teaching labs for four weeks. Eighty students from the eighth semester of FMVZ-USP were divided into four groups, each participating in one lab per week. The cadavers were randomly allocated to one of the four groups in the first week, and reutilized at 7-day intervals. At the end of each lab, cadavers were inspected for signs of putrefaction and stored in a cold chamber until further use. Thawing and washing procedures were carried out 24 hours before the next lab, as 
previously described.

Training for procedures involving different structures and systems were carried out each week as follows: week one, skin (nodule resection and suture techniques); week two, eyes and adnexa; week three, esophagus, trachea, and salivary glands; and week four: ears and oral cavity. Training for skin preparation procedures was also conducted.

Data on the state of preserved cadavers were collected at the end of each session over the four weeks of the experimental period. The following criteria were considered: general appearance (i.e., no signs of putrefaction, signs of putrefaction with mild skin changes, incipient putrefaction, or putrefaction), muscle tissue color, tissue texture/consistency, joint flexibility, odor development, and skin integrity.

The analysis of the parameters was performed by the first two authors of the article along with the teacher responsible for the class on the evaluation day. None of the evaluators were aware of the group of the cadaver being evaluated.

The parameters most similar to living tissue were considered normal. The tissue texture classification was performed after excision and suturing. The joint flexibility was measured by flexing the thoracic and pelvic limbs of the corpse in lateral decubitus position (Table 3). Statistical analysis was based on the chi-square test at a $5 \%$ level of significance.

Table 3. Evaluation of characteristics

\begin{tabular}{|c|c|}
\hline \multicolumn{2}{|c|}{ General aspect } \\
\hline 1. & Absence of signs of putrefaction, absence of skin changes \\
\hline 2. & No signs of putrefaction, slight skin changes \\
\hline 3. & Beginning of putrefaction \\
\hline 4. & Putrefaction \\
\hline \multicolumn{2}{|c|}{ Muscle color } \\
\hline 1. & Pale \\
\hline 2. & Normal \\
\hline 3. & Darkened \\
\hline \multicolumn{2}{|c|}{ Tissue consistency/texture } \\
\hline 1. & Softened \\
\hline 2. & Firm \\
\hline 3. & Hardened \\
\hline \multicolumn{2}{|c|}{ Flexibility of joints } \\
\hline 1. & Softened \\
\hline 2. & Normal \\
\hline 3. & Hardened \\
\hline \multicolumn{2}{|c|}{ Inguinal abdominal skin } \\
\hline 1. & Desquamation \\
\hline 2. & Without Desquamation \\
\hline \multicolumn{2}{|c|}{ Odor } \\
\hline 1. & Absent \\
\hline 2. & Present \\
\hline \multicolumn{2}{|c|}{ Skin of regions of surgical access } \\
\hline 1. & Desquamation \\
\hline 2. & Without Desquamation \\
\hline
\end{tabular}




\section{Results}

There was no significant difference in cadaver preservation with $20 \%$ and $10 \%$ Larssen solution $(\mathrm{p}>0.05)$. All cadavers remained in a good state of preservation over the course of the experimental period. Mild skin changes did not interfere with surgical procedures (Figures 1 and 2). One cadaver from the G1 group developed incipient putrefaction in the second week, but did not undergo further deterioration over the next two weeks. Incipient putrefaction was noted in two cadavers of the G2 group in the last week of the experimental period (Table 4).

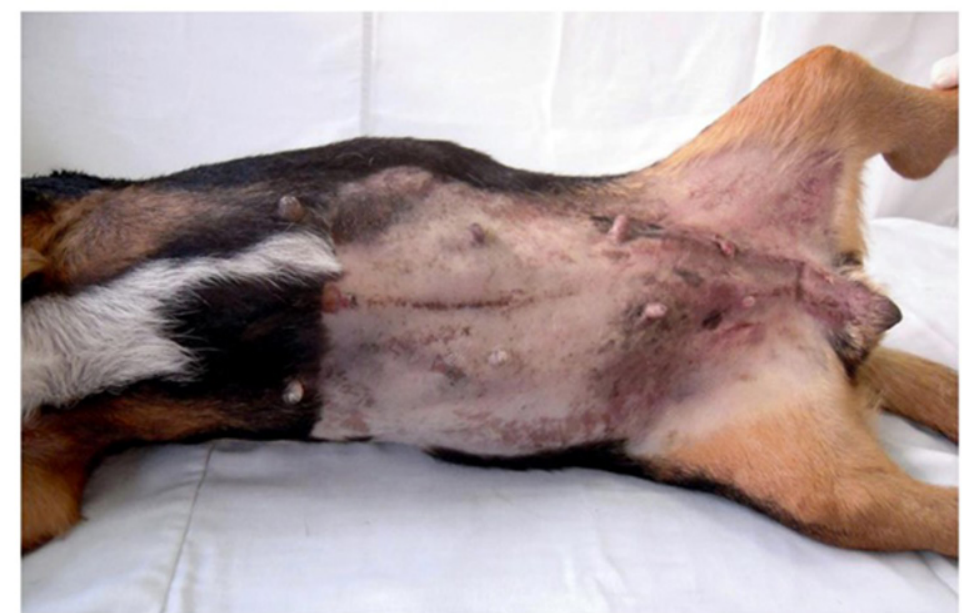

Figure 1. Group 1 cadaver: small changes in the skin color in the inguinal region (second week)

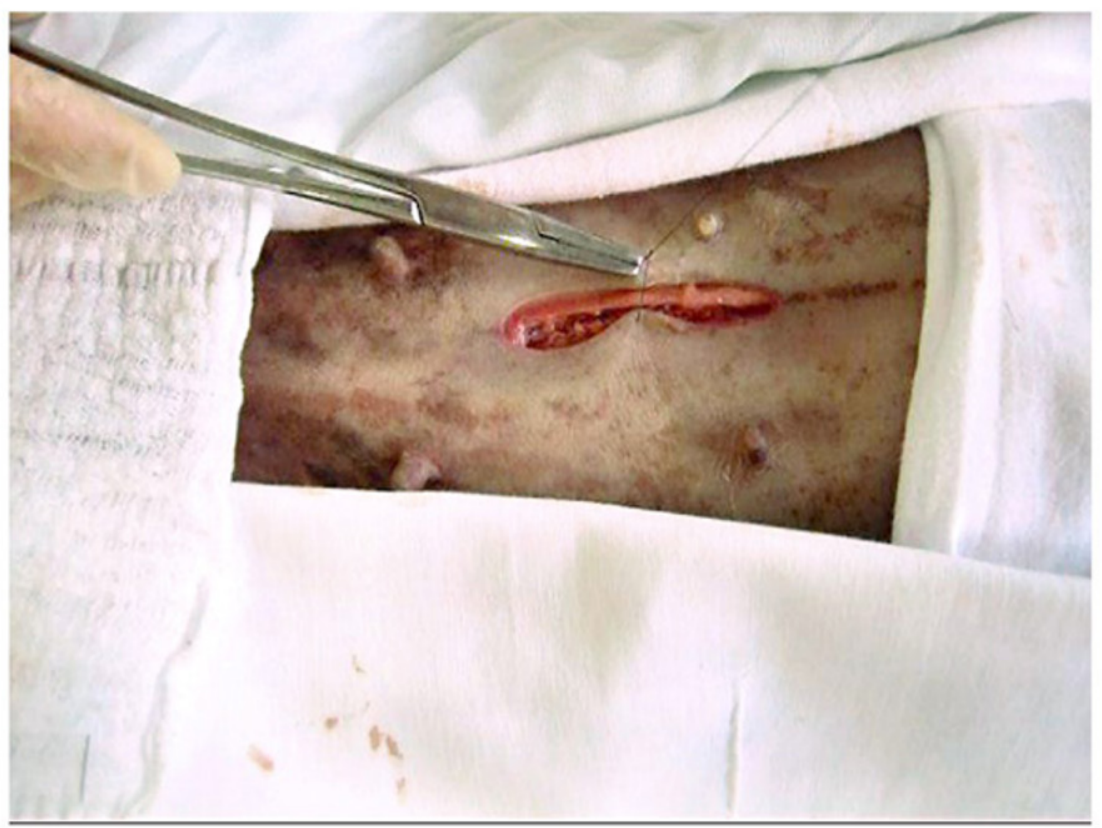

Figure 2. Group 1 cadaver: Surgical field; retention of life-like skin and muscle tissue color (second week) 
Table 4. Presentation of the general aspects observed during four weeks in group 1 (G1) and group 2 (G2) (percentage)

\begin{tabular}{ccccc}
\hline & $\begin{array}{c}\text { Week 1 } \\
\mathbf{( \% )}\end{array}$ & $\begin{array}{c}\text { Week 2 } \\
\mathbf{( \% )}\end{array}$ & $\begin{array}{c}\text { Week 3 } \\
\mathbf{( \% )}\end{array}$ & $\begin{array}{c}\text { Week 4 } \\
\mathbf{( \% )}\end{array}$ \\
General aspect & $\mathbf{G 1 / G 2}$ & $\mathbf{G 1 / G 2}$ & $\mathbf{G 1 / G 2}$ & $\mathbf{G 1 / G 2}$ \\
\hline $\begin{array}{c}\text { Absence of signs of } \\
\text { putrefaction, absence } \\
\text { of skin changes }\end{array}$ & $75.0 / 66.67$ & $41.67 / 41.67$ & $41.67 / 33.33$ & $25.0 / 25.0$ \\
$\begin{array}{c}\text { No signs of } \\
\text { putrefaction, slight } \\
\text { skin changes }\end{array}$ & $25.0 / 33.33$ & $50.0 / 58.33$ & $50.0 / 58.33$ & $66.67 / 58.33$ \\
$\begin{array}{c}\text { Beginning of } \\
\text { putrefaction }\end{array}$ & $0.0 / 0.0$ & $8.33 / 0.0$ & $8.33 / 8.33$ & $8.33 / 16.67$ \\
Putrefaction & $0.0 / 0.0$ & $0.0 / 0.0$ & $0.0 / 0.0$ & $0.0 / 0.0$ \\
\hline
\end{tabular}

Muscle tissue discoloration was the most significant macroscopic finding in this study, with six cadavers in each group showing darker muscle tissues in the fourth week of the experimental period (Table 5).

Table 5. Presentation of the musculature color observed during four weeks in group 1 (G1) and group 2 (G2) (percentage)

\begin{tabular}{lcccc}
\hline Muscle color & $\begin{array}{c}\text { Week 1 } \\
\mathbf{( \% )}\end{array}$ & $\begin{array}{c}\text { Week 2 } \\
\mathbf{( \% )}\end{array}$ & $\begin{array}{c}\text { Week 3 } \\
\mathbf{( \% )}\end{array}$ & $\begin{array}{c}\text { Week 4 } \\
\mathbf{( \% )}\end{array}$ \\
& $\mathbf{G 1 / G 2}$ & $\mathbf{G 1 / G 2}$ & $\mathbf{G 1 / G 2}$ & $\mathbf{G 1 / G 2}$ \\
\hline Pale & $16.67 / 16.67$ & $25.0 / 8.33$ & $16.67 / 25.0$ & $33.33 / 41.67$ \\
Normal & $75.0 / 50.0$ & $66.67 / 75.0$ & $50.0 / 25.0$ & $16.67 / 8.33$ \\
Darkened & $8.33 / 33.33$ & $8.33 / 16.66$ & $33.33 / 50.0$ & $50.0 / 50.0$ \\
\hline
\end{tabular}

No changes in tissue texture/consistency or tissue/joint flexibility were noted in G1 cadavers; however, one G2 cadaver showed softer tissues and joints than normal since the first week (Tables 6 and 7).

Table 6. Presentation of tissue consistency/texture observed during four weeks in group 1 (G1) and group 2 (G2) (percentage)

\begin{tabular}{lcccc}
\hline \multicolumn{1}{c}{ Tissue } & Week 1 & Week 2 & Week 3 & Week 4 \\
consistency/texture & $\mathbf{( \% )}$ & $\mathbf{( \% )}$ & $\mathbf{( \% )}$ & $\mathbf{( \% )}$ \\
& G1/G2 & G1/G2 & G1/G2 & G1/G2 \\
\hline Softened & $0.0 / 8.33$ & $0.0 / 8.33$ & $0.0 / 8.33$ & $0.0 / 8.33$ \\
Firm & $100 / 91.67$ & $100 / 91.67$ & $100 / 91.67$ & $100.0 / 91.67$ \\
Hardened & $0.0 / 0.0$ & $0.0 / 0.0$ & $0.0 / 0.0$ & $0.0 / 0.0$ \\
\hline
\end{tabular}


Table 7. Presentation of flexibility of joins observed during four weeks in group 1 (G1) and group 2 (G2) (percentage)

\begin{tabular}{lcccc}
\hline $\begin{array}{c}\text { Flexibility of } \\
\text { joints }\end{array}$ & $\begin{array}{c}\text { Week 1 } \\
\mathbf{( \% )}\end{array}$ & $\begin{array}{c}\text { Week 2 } \\
\mathbf{( \% )}\end{array}$ & $\begin{array}{c}\text { Week 3 } \\
\mathbf{( \% )}\end{array}$ & $\begin{array}{c}\text { Week 4 } \\
\mathbf{( \% )}\end{array}$ \\
& $\mathbf{G 1 / G 2}$ & $\mathbf{G 1 / G 2}$ & $\mathbf{G 1 / G 2}$ & $\mathbf{G 1 / G 2}$ \\
\hline Softened & $0.0 / 8.33$ & $0.0 / 8.33$ & $0.0 / 8.33$ & $0.0 / 8.33$ \\
Normal & $100.0 / 91.67$ & $100.0 / 91.67$ & $100.0 / 91.67$ & $100.0 / 91.67$ \\
Hardened & $0.0 / 0.0$ & $0.0 / 0.0$ & $0.0 / 0.0$ & $0.0 / 0.0$ \\
\hline
\end{tabular}

Abdominal and inguinal skin scaling were the second most relevant macroscopic changes in the cadavers analyzed, affecting three G1 and seven G2 cadavers. Changes occurred at the end of the experimental period (Table 8).

Table 8. Presentation of inguinal abdominal skin observed during four weeks in group 1 (G1) and group 2 (G2) (percentage)

\begin{tabular}{|c|c|c|c|c|}
\hline $\begin{array}{c}\text { Inguinal } \\
\text { abdominal skin }\end{array}$ & $\begin{array}{c}\text { Week } 1 \\
(\%) \\
\text { G1/G2 }\end{array}$ & $\begin{array}{c}\text { Week } 2 \\
(\%) \\
\text { G1/G2 }\end{array}$ & $\begin{array}{c}\text { Week } 3 \\
(\%) \\
\text { G1/G2 }\end{array}$ & $\begin{array}{c}\text { Week } 4 \\
(\%) \\
\text { G1/G2 }\end{array}$ \\
\hline Desquamation & $8.33 / 16.67$ & $8.33 / 25.0$ & $16.67 / 41.65$ & $25 / 58.33$ \\
\hline $\begin{array}{c}\text { Without } \\
\text { Desquamation }\end{array}$ & $91.67 / 83.33$ & $91.67 / 75.0$ & $83.33 / 58.35$ & $75 / 41.67$ \\
\hline
\end{tabular}

Foul odor was noted in one G1 cadaver right from the beginning, and in the last week of the experimental period in another. One G2 cadaver developed foul odor from the second week (Table 9).

Table 9. Presentation of odor observed during four weeks in group 1 (G1) and group 2 (G2) (percentage)

\begin{tabular}{lcccc}
\hline \multicolumn{1}{c}{ Odor } & $\begin{array}{c}\text { Week 1 } \\
\mathbf{( \% )}\end{array}$ & $\begin{array}{c}\text { Week 2 } \\
\mathbf{( \% )}\end{array}$ & $\begin{array}{c}\text { Week 3 } \\
\mathbf{( \% )}\end{array}$ & $\begin{array}{c}\text { Week 4 } \\
\mathbf{( \% )}\end{array}$ \\
& G1/G2 & G1/G2 & G1/G2 & G1/G2 \\
\hline Absent & $91.67 / 100.0$ & $91.67 / 91.67$ & $91.67 / 91.67$ & $83.33 / 91.67$ \\
Present & $8.33 / 0.0$ & $8.33 / 8.33$ & $8.33 / 8.33$ & $16.67 / 8.33$ \\
\hline
\end{tabular}

Skin scaling affecting the lateral surface of the thorax was documented in one G1 cadaver in the first week of the experimental period; however, no scaling occurred in other areas submitted to surgical procedures over the course of the following weeks. In G2, three cadavers developed skin scaling: one in the first and fourth week and two in the second week (Table 10). 
Table 10. Presentation of skin of regions of surgical access observed during four weeks in group 1 (G1) and group 2 (G2) (percentage)

\begin{tabular}{|c|c|c|c|c|}
\hline $\begin{array}{c}\text { Skin of regions } \\
\text { of surgical } \\
\text { access }\end{array}$ & $\begin{array}{c}\text { Week 1 } \\
(\%) \\
\text { G1/G2 }\end{array}$ & $\begin{array}{c}\text { Week 2 } \\
(\%) \\
\text { G1/G2 }\end{array}$ & $\begin{array}{c}\text { Week } 3 \\
(\%) \\
\text { G1/G2 }\end{array}$ & $\begin{array}{c}\text { Week } 4 \\
(\%) \\
\text { G1/G2 }\end{array}$ \\
\hline Desquamation & $8.33 / 8.33$ & $0.0 / 16.67$ & $0.0 / 0.0$ & $0.0 / 8.33$ \\
\hline $\begin{array}{c}\text { Without } \\
\text { desquamation }\end{array}$ & $91.67 / 91.67$ & $100.0 / 83.33$ & $100.0 / 100.0$ & $100.0 / 91.67$ \\
\hline
\end{tabular}

\section{Discussion}

The cadavers in the G1 and G2 groups did not differ significantly in this study. Higher dilution yielded 1.46 times larger volumes of solution in G1 compared to solution in G2; therefore, a larger number of cadavers could be prepared using similar amounts of chloral hydrate, sodium bicarbonate, sodium sulphate, sodium chloride, and glycerin, at lower costs and equivalent efficacy.

Animal cadavers showed good general appearance (i.e., no signs of putrefaction or skin changes) at the time of preservation in this study and retained satisfactory conditions for use throughout the experimental period. Cadaver evaluation prior to preservation should be emphasized, and only those in good conditions should be selected for embalming. One G1 cadaver developed incipient putrefaction in the second week. The reason for this change is uncertain because the corpse was in a good condition at the time of embalming. The incipient putrefaction observed in two corpses of the G2 group occurred similar to that in previous years. Furthermore, the cadavers preserved with this formulation also presented changes in the last week of training. This indicated a need to improve the formula.

Hygiene procedures were paramount to minimize odor development and remove debris. As proposed in this study, repeated washing with neutral soap and shampoo following embalming and prior to use is highly recommended. Formulation-specific preservation protocols must be strictly followed, because changes could compromise the outcomes.

Successful surgical skill trainings with animal cadavers obtained from veterinary hospitals and animal shelters have been reported ${ }^{(5)}$. The use of cadavers has several advantages, including high anatomical fidelity and faithful simulation of real-life situations ${ }^{(6)}$. Cadavers are amenable to repeated use. Therefore, all students have a chance to perform most of the procedures ${ }^{(7)}$. On the other hand, techniques executed on live animals, offer limited opportunities for student participation ${ }^{(6)}$. In this study, cadavers preserved with modified Larssen solution and stored at freezing temperatures could be repeatedly used over a 4-week period, with satisfactory retention of organoleptic properties required for appropriate surgical training.

A previous study shows that students undergoing cadaver-based surgical training develop similar proficiency as those using live animals ${ }^{(3)}$. This supports the need for continuous improvement and innovation of alternative teaching methods.

Several formulations have been created to achieve better and long-lasting cadaver preservation. 
Formaldehyde, ethyl alcohol, and glycerin are the most common chemicals used for this purpose; however, other compounds, such as phenolics, other aldehydes, halogenated compounds, oxidizing agents, heavy metals and their salts, sulphur, and thiosulphates can also be employed as preservatives to reduce the proliferation of microorganisms ${ }^{(8)}$.

Animal cadavers preserved by traditional methods do not retain organoleptic characteristics that are deemed essential for surgical training. Among the components of the modified Larssen solution, sodium sulphate and chloral hydrate have clot-dissolving properties and promote blood drainage, glycerol contributes to preservation of joint flexibility, and formalin permits long-term storage and use $^{(4,9)}$. However, excessive formalin concentrations cause changes in tissue texture and color, in addition to the generation of strong odor. The use of this fixative is limited in cadavers destined for surgical training ${ }^{(10)}$. Lower formalin concentrations are thought to be an advantage of the modified Larssen solution $^{(4)}$. Formalin-related tissue compromise was not documented in this study.

Similar to the modified Larssen solution, the most commonly used preservation method described by Thiel (1992) ${ }^{(11)}$ is thought to promote good retention of tissue color, consistency, and transparency, with the added benefit of reduced release of noxious substances into the environment. However, several aspects of this embalming procedure, such as the volume of solution to be injected, have not been standardized and require further investigation. Additionally, cadavers preserved in this manner tend to swell ${ }^{(12)}$. Edema development was not documented in cadavers in this study, but escape of fluid through natural openings did occur during the fixation procedure.

The Klotz solution is yet another embalming fluid with composition similar to modified Larssen solution (i.e., chloral hydrate, sodium bicarbonate, sodium chloride, and formalin). However, its preparation requires the use of $40 \%$ formalin and fixation is achieved by immersion, which is a slower method than is vascular perfusion ${ }^{(4,8)}$.

Studies comparing the Laskowski and modified Larssen solutions have been published ${ }^{(12)}$. The solution developed by Laskowski contains glycerin, ethanol, and phenic and boric acid and prevents dehydration while permitting good tissue color and plasticity retention ${ }^{(9)}$. However, Silva et al. ${ }^{(12)}$ reported the need to replace $50 \%$ of cadavers preserved with this solution after the first week of use due to development of darker muscle tissue color, softer tissue texture, skin scaling, and strong sweet odor, despite good joint flexibility. In contrast, cadavers preserved with the modified Larssen solution did not develop any of the aforementioned changes and retained tissue properties closely resembling those of living tissues throughout the surgical training period in that study ${ }^{(12)}$.

As reported by Silva et al. ${ }^{(12)}$, cadaver replacement because of changes that might interfere with surgical training, such as odor development, was not required in this study. However, slightly darker color of muscle tissue was documented in $50 \%$ of cadavers in each experimental group, and $33 \%$ of cadavers developed abdominal skin scaling. The reason for the darkening of the muscles is unknown. It was probably because of the formalin or the freezing process; however, this alteration was discrete and did not affect students' learning.

\section{Conclusion}

All cadavers in this study provided appropriate conditions for the training of different surgical procedures. The use of a more dilute modified Larssen solution with higher formalin concentration had no negative impact on cadaver organoleptic properties, and therefore did not compromise the 
learning process. Hence, this solution was considered a cheaper alternative to the original formulation.

\section{Conflict of interest statement}

The authors of this study have no conflict of interest to declare.

\section{Acknowledgments}

The authors thank FAPESP (São Paulo Research Foundation) for funding this study.

\section{References}

1. Diniz R, Duarte ALA, Oliveira CAS, Romiti M. Animais em Aulas Práticas: Podemos Substituí-los com a Mesma Qualidade de Ensino? Revista Brasileira de Educação Médica. 2006;30:31-41. Portuguese http:// $\underline{\text { www.scielo.br/scielo.php?script }=\text { sci arttext\&pid }=\text { S0100-55022006000200005 }}$

2. Danielski JCR. Ciência de Animais de Laboratório: Um Paradigma Atual na Educação e Pesquisa Acadêmica. Programa de Pós Graduação Educação em Ciências, Universidade Federal do Rio Grande, FURG, Rio Grande, RS, Brasil. 2010. Portuguese http://repositorio.furg.br/handle/1/3563

3. Buyukmihci NC. Non-violence in surgical training. UC Davis. Previously published works 2016. http:// escholarship.org/uc/item/9fp1m35p\#page-3.com

4. Silva RMG, Matera JM, Ribeiro AACM. New Alternative methods to teach surgical techniques for veterinary medicine students despite the absence of living animals: Is that an Academic Paradox? Anatomy, Histology, Embryology. 2007;36:220-4. http://onlinelibrary.wiley.com/doi/10.1111/j.1439-0264.2007.00759.x/ $\underline{\text { abstract }}$

5. Duffe N. Alternative training methods I: Proceedings of the 1998 LAWTE Meeting. Laboratory Animal. 1999;28(5):32-6.

6. Presgrave OAF, Caldeira C, Gimenes I, Freitas JCBR, Nogueira STB, Oliveira NDE, et al. Métodos alternativos ao uso de animais: uma visão atual. Ciência Veterinária nos Trópicos. 2010;13(1):106-17. https://www.bvs-vet.org.br/vetindex/periodicos/ciencia-veterinaria-nos-tropicos/13-(2010)/ metodos-alternativos-ao-uso-de-animais-uma-visao-atual//

7. Balcome J. The use of animals in higher education: problems, alternatives, and recommendations. Washington. The Humane Society Press. 2000:104. http://www.humanesociety.org/assets/pdfs/parents educators/ the use of animals in higher ed.pdf

8. Rodrigues, H. Técnicas Anatômicas (Anatomical Techniques). 3rd ed Vitória: Edison Arte, 2005.229p. Portuguese.

9. Sampaio FJB. Analysis of kidney volume growth during the fetal period in humans. Urological Research. 1992;20:271-4. http://link.springer.com/article/10.1007/BF00300257

10. Groscurth P, Eggli P, Kapfhammer GR, Hornung JP, Fasel JDH. Gross anatomy in the surgical curriculum in Switzerland: Improved cadaver preservation, anatomical models, and course development. The Anatomical Record. 2001;256:254-6. http://onlinelibrary.wiley.com/doi/10.1002/ar.10030/pdf

11. Willaert W, De Vos M, Van Hoof T, Delrue L, Pattyn P, D’Herde K. Understanding thiel embalming in pig kidneys to develop a new circulation model. PloS One. 2015;10(3). http://journals.plos.org/plosone/ 
article?id=10.1371/journal.pone.0120114

12. Silva RMG, Matera JM, Ribeiro AACM. Preservation of cadavers for surgical technique training. Veterinary Surgery. 2005;33:606-8. http://onlinelibrary.wiley.com/doi/10.1111/j.1532-950x.2004.04083.x/abstract 